\title{
The Plant Variety Protection Law in Malaysia: Issues on Protection of Farmers' Rights
}

\author{
Murshamshul Kamariah Musa (Corresponding author) \\ Faculty of Law and International Relations, Universiti Sultan Zainal Abidin \\ 21300, Kuala Terengganu, Terengganu, Malaysia \\ Tel: 60-9-668-8477Ｅ-mail: mksham.musa@gmail.com
}

\begin{abstract}
Zuhairah Arif Abd Gadas
Faculty of Law And International Relations, University Sultan Zainal Abidin 21300, Kuala Terengganu,Terengganu, Malaysia

Tel: 60-9-668-8477Ｅ-mail: zuhairahariff@unisza.edu.my

Mohd Shahril Nizam Md Radzi (Corresponding author) Faculty of Entrepreneurship and Business, Universiti Malaysia Kelantan 16100, Kota Bharu Kelantan, Malaysia

Tel: 60-9-771-7251 E-mail: shahrilnizam@umk.edu.my
\end{abstract}

Received: July 10, 2014 Accepted: August 2, 2014 Published: February 1, 2015

doi:10.5296/jmr.v7i2.6941 URL: http://dx.doi.org/10.5296/jmr.v7i2.6941

\begin{abstract}
The availability of a wide diversity of plant genetic resources for food and agriculture is necessary to ensure continuous food production and food security. However, the expansion of intellectual property protection into agricultural field has raised concerns as to its impact on farmers' traditional agricultural practises and the recognition of farming communities' efforts in development and conservation of plant varieties. This paper serves as an exploratory study on few issues relating to farmers in Malaysia, the Farmers' Rights concept and plant variety rights in Malaysia. The paper provides a brief review on the current Malaysian plant variety law and suggests further in depth study to identify gaps in the current legislation in realising
\end{abstract}


the four core components of the Farmers' Rights concept.

Keywords: Farmers' Rights, Plant varieties rights, Intellectual property law, FAO Treaty, Farmers 


\section{Introduction}

Farmers have been using plants and animal genetic resources for a long time for breeding purposes. Recent developments in modern biotechnology, particularly via genetic engineering methods; have significantly increased the use and value of these genetic resources in the breeding industry (Girsberger,1999). Plant genetic resources (henceforth referred as PGR) play a vital role towards the betterment of global nutrition and health. According to Nadine, Sperling and Ahsby as the main source of genetic material for development of food crops and medicinal plants, PGR value in the world's economy is incalculable (Saad, Sperling \&Ashby, 2009). It is the most essential category of biological resources providing foundation for all food production and the key to feeding unprecedented number of people in times of climate and environmental change.

Farmers value plants not only for their obvious benefits to humans but most importantly, for their inherent genetic traits. To ensure food security, every nation depends on food crops domesticated either locally or elsewhere and the interdependence levels between countries for agricultural PGR are high (Fowler and Hodgkin, 2004). Various types of PGR are developed, enhanced and conserved by farmers globally, rich and poor, and these particular communities continue to be the stewards of PGR through their own methods of selection, refining, maintaining, sharing and trading these particular genetic resources throughout their farming activities (Swaminathan, 1998).

Plant genetic resource for food and agriculture (henceforth referred as PGRFA) is another term for food crop plants and is an important class of PGR which are essentially man-made. Girsberger stressed the high value attached to this particular group of PGR in plant breeding activities, as it assists in developing new and better varieties of crops (Girsberger, 1999). The diversity of genetic materials contained in PGRFA either from traditional farmers' grown varieties, modern breeds of crops or wild relatives of these PGRFA, constitute an important component of agro biodiversity (Food and Agriculture Organisation, 1998). Through knowledge and expertise passed on from one generation to another, farmers have contributed to the creation, conservation, exchange and knowledge of genetic and species diversity of PGRFA. Through their practises of seed selections for re-planting purposes, farmers have built up genetic diversity of crops with increased quality in terms of palatability and storage quality. Seeds are chosen based on specific characteristics deemed appropriate by farmers for their farming environment, with high economic value, displaying agronomic stability and tolerance to disease and pests. These seeds are acquired either from the harvest of their own fields or through sale or exchange with neighbouring farming communities (Mushita, 1992).

Alteiri maintained that farmers' efforts at maintaining genetic diversity of PGRFA, particularly of the major staple crops of subsistence farmers, have helped in food security by offering greater defences against vulnerability to diseases, pests and environmental changes as well as enhancing harvest security (Alteiri, 2009). To ensure food security for their households, the majority of subsistence and resource-poor farmers in developing countries continue their reliance on the traditional practices of saving, exchanging and selling the seeds from their own harvest. Farmers are able to gain access to different genetic varieties of crops 
through this informal seed system, allowing them to select desired traits and improve their traditional crop varieties to better suit the local environment. The informal communal seed system, which values agricultural biodiversity, created and preserved such diversity to be in tandem with local environment (Brush, .

\section{Innovation and Farmers}

The innovation and growing knowledge in genetics have consequently changed plant breeding into a more complex, scientific process involving a greater degree of strategic manipulations. This evolutionary process of agriculture involving plant genetic resources has directly affected the farming community. Borowiak pointed out that the process now resembles modes of industrial innovations and production which shifted the breeding of new varieties of plants from farmers' field to scientists' laboratories (Borowiak, 2004). The expansion of intellectual property rights (henceforth referred as IPRs) particularly plant varieties rights and patents into PGR, has created controversies about the farmers-centred practices. The private and individual nature of the IPRs is at odds with the traditional farming practices which are deeply rooted in communal good. The farmers may be considered as committing criminal acts of piracy when they continue with their millennium-old practices of saving, selecting, selling and exchanging seeds from their own field with other farmers (Borowiak, 2004).

Oguamanam (2006) stresses that these traditional agricultural practices combined with modern day agricultural biotechnology are two primary approaches to tackle food security concerns. The farmers' practises boost genetic diversity of PGRFA ensuring continuous supply of raw materials for modern plant breeding which make full use of the most recent biotechnology techniques to create new varieties of crop plants for agricultural uses. Both methods are mutually beneficial and contribute to global food production. He also points out that despite the mutual beneficial relationship between traditional farming practises and modern agricultural biotechnology, issues of reward and protection between the two parties' remains contentious from both a legal and policy perspective. He further argues that IPR, in the form of plant breeders' rights (hereinafter referred as PBR) and patents, which are used as mechanism for reward and protection of knowledge, is unable to provide the proper balance of rights and responsibilities between the two parties. He concludes that supporting legal framework which undermines the role of traditional farmers and their agricultural practises, in favour of modern agro-biotech practitioners, may hamper efforts of food security and sustainable agriculture as it would result in farmers depending upon corporate seed producers and monopolies of the biotechnology proprietors (Oguamanam, 2006).

Plant variety protection (PVP) or also known as plant breeders' rights (PBR) is a form of intellectual property rights which grants exclusive rights to breeders of new varieties of plants to exploit their varieties. This particular right enables the holder of such right to restraint others from reproducing a new plant variety which has been protected under it. Biber-Klemm and Cottier described this right as an independent sui generis form of protection specifically tailored for the purpose of protecting new plant varieties (Biber-Klemm \& Cottier, 2006). Similar to other IPRs, it grants the holder of a plant variety right an exclusiveness of 
ownership subject to similar limitations which are quite common to other IPRs. The exclusive rights granted to breeders are to ensure the breeders of their opportunity to recoup the expenses of their research into a new or improved plant variety. It was argued that the exclusive rights granted to the breeders should be balanced with a society's legitimate rights the rights of its farmers and agricultural communities, to be recognised in any plant variety protection legislation. The opening to do so, present itself through the concept of Farmers' Rights (SEATINI, 2010).

The importance of PGRFA's diversity and farmers' contributions towards agricultural diversity and food security is recognised by the Food and Agriculture Organization of the United Nations (henceforth referred as FAO). As a specialised agency established in 1945 under the auspices of United Nations, FAO is an intergovernmental organisation which is linked to the UN Economic and Social Council. FAO efforts are all aimed towards achieving food security for all, ensuring people regular access to enough and quality to sustain healthy lives. The International Treaty on Plant Genetic Resources for Food and Agriculture (henceforth referred as FAO Treaty) via Paragraph 4 of its Preamble, acknowledges the enormous role of PGRFA in achieving the goals of Rome Declaration on World Food Security in 1996.Gibson (2012) concede that both the World Food Summit Plan of Action (Objective 2.1 (f)) and the FAO Treaty as important documents which provide the initial framework for ongoing efforts to eliminate hunger (Gibson, 2012). The FAO Treaty, under Article 3 clearly indicates its focus which relates exclusively on PGRFA promotes conservation and the sustainable use of PGRFA to ensure genetic diversity and food security. In order to achieve these aims, the FAO Treaty proposes implementation mechanisms in the form of Farmers' Rights concept, a multilateral system of benefit sharing and a funding strategy (Moore \& Tymowski, 2005).

The role and contribution of farmers globally towards the conservation and development of PGRFA diversity, is affirmed in Paragraph 7 of the Preamble to FAO Treaty which also introduces the concept of Farmers' Rights.

Affirming that the past, present and future contributions of farmers in all regions of the world, particularly those in centres of origin and diversity, in conserving, improving and making available these resources, is the basis of Farmers' Rights.

Such affirmation is again confirmed in Article 9.1 of the FAO Treaty, emphasising the importance of PGRFA as a source for food and agricultural production globally and the role played by farmers in conservation and development of PGRFA.

Article 9.1 of the FAO Treaty states as follows:

"The Contracting parties recognise the enormous contribution that the local and indigenous communities and farmers of all regions of the world, particularly those in the centres of origin and crop diversity, have made and will continue to make for the conservation and development of plant genetic resources which constitute the basis of food and agriculture production throughout the world." 


\section{Farmers' Rights}

Farmers' Right is a concept which seeks to recognise the contributions of traditional farmers, particularly in the developing world towards the preservation, improvement and conservation of plant genetic resources in the agricultural field. This concept called for a recognition and reward to farmers for their effort in conservation of plant genetic diversity and protection of farmers' traditional farming and seed-saving practises from the ambit of breeders' exclusive rights. These rewards can either be monetary and non-monetary through benefit-sharing mechanisms or by enabling farmers to claim exclusive rights over plant varieties which they cultivate traditionally (SEATINI, 2010). Four core principles of Farmers Rights concept has been articulated under Article 9 of the FAO Treaty to be carried out by national governments as a measure towards strengthening the rights of farmers. The four core principles namely right to seeds, right to traditional knowledge, right to equitable benefit sharing and right to participate in decision making should be given legal status either by adopting is as part of a legislation or policies benefiting the farming communities particularly for small holder farmers in developing countries such as Malaysia. Falvey identified the undeniable link between the pivotal roles which farmers, particularly smallholding farmers, in ensuring continuity of food production and security as crucial in the development of a nation (Falvey, 2010). Thus, there is an urgent need for national governments particularly from developing countries of which Malaysia is one, to pay greater attention to these farmers.

Under the FAO Resolution 5/89, the international community was vested and entrusted, to support farmers for their continuous contributions to the conservation and sustainable use of PGRFA by providing funds and assistance to these farmers and ensuring full benefit-sharing from commercial uses of any these resources (Andersen, 2008). Despite this appeal to the international community, responsibility for implementing the Farmers' Rights concept, as officially recognised by the FAO Treaty, under Article 9.2, rests upon national governments. The biggest challenge at present is translating Farmers' Rights into practical realisation due to its broad definition under the FAO Treaty, as it has proven to be quite difficult to enact despite being widely discussed at international fora. Suggestions of measures for the protection and promotion of rights of farmers have been made in the FAO Treaty, nonetheless they are not legally binding, leaving governments with the freedom to choose the most appropriates measures they deem fit and appropriate to suit their needs and priorities. Being voluntary measures which can be subjected to a country's national legislation, the furtherance of these measures namely the rights to protection of traditional knowledge, benefit sharing and participation in decision-making processes are dependent on the political will within the governments and demands from civil society organisations and interested groups (Andersen, 2008)

\section{The Issues}

In order to ensure the continuing and security of food production and crop genetic diversity, there is a need to address the ability of farmers to continue their farming practices of seed saving, exchange and to have autonomy over their own seeds. The possibility of doing arises through the implementation and/or strengthening of Farmers' Rights concept by each 
individual country. Farmers' traditional seed saving practises have been increasingly delegitimised due to the enlargement of IP rights into agriculture. Borowiak (2004) views the Farmers' Rights concept as a 'strategy of resistance' against the perceived inequities of IPR regimes for PGRFA. He postulates that the concept should be recognised as a unique form of right - different from PBR to avoid the possibility of the concept from succumbing to the same fallacies and inequities which have triggered it in the first place. The Farmers' Rights concept can provide a platform whereby farming communities can demand and seek better recognition for their contributions, together with increased autonomy over their seeds and traditional agricultural practices. He argued that the Farmers' Rights concept is better suited than the conventional IPR to encourage innovations in farming communities and for registering innovations which are derived from communally owned knowledge (Borowiak, 2004).

The small farming communities who plays a vital role in food security as the conserver and stewards of plant genetic diversity especially PGRFA, should be recognised and rewarded for their continuous efforts. The support and recognition through Farmers' Rights does not mean only monetary gains should be given to them, but also other kind of sharing such as support in conservation effort and facilitating access to better seed varieties and cooperation with small breeders. Such efforts are crucial in providing an incentive in the development of PGRFA, as the basis of food and agriculture production.

Although a framework is already in place for the realisation of the Farmers' Rights as perceived under Article 9 of the FAO Treaty, it has not created a deep impact on the global community. Regardless of the slow process at the international level, individual states should play a more active role towards the realisation of Farmers' Rights especially in the developing countries to ensure the continuous livelihood of the large population of rural farming communities in those regions. Instead of competing or trying to be IPR-like, Farmers' Rights should reflect the particular needs and address the concerns of each particular country as echoed throughout the FAO Treaty. Thus it is essential to guarantee that the small resource farmers are not left out for equity reasons by creating policies which recognises their essential role in food production. These policies may include the empowerment of farmers by including the four core rights as enumerated under Article 9 of the FAO Treaty in Malaysian legislations namely the rights of farmers to their saved seed, right to traditional knowledge, their right to equitable benefit-sharing and their right to participate in decision making processes. Small farmers who are the first link to conservation of crop diversity and continuous food production may have a bigger say through this concept. The advocates for empowerment of small farmers in Malaysia stress more on the small farmers' economic improvement (Fahmi, Abu Samah \& Abdullah, 2013; Mahmudul Alam, Siwar, Molla \& Toriman, 2010) rather than the empowerment of their legal rights as enumerated earlier under the four core components of Farmers' Rights concept.

Malaysia acceded to the International Treaty on Plant Genetic Resources for Food and Agriculture (FAO Treaty) on 5 May 2003 as part of its international commitments (Ministry of Foreign Affairs, Malaysia). As previously illustrated, the Treaty recognises the contributions of farmers to the development and conservation of plant genetic resources for 
food crops and agriculture through a concept known as Farmers' Rights. As one of the member of the World Trade Organizations (WTO) which regulates international trade between governments and in compliance with the requirement of Article 27.3(b) of Agreement on Trade-Related Aspects of Intellectual Property Rights (TRIPS) which is a trade instrument under the auspices of WTO, Malaysia has enacted the Protection of New Plant Varieties Act of 2004. This legislation grants exclusive intellectual property rights - the plant variety protection rights (PVP), to plant breeders as well as recognising the contributions of locals and indigenous farming communities in the development of plant varieties. The Protection of New Plant Varieties Act 2004 (PNPV Act 2004) is an intellectual property legislation that specifically regulates farmers' rights and new plant variety in Malaysia. The Act was gazetted on 1 July 2004 and came into operation since 20 October 2008. This Act is supplemented by the Protection of New Plant Varieties Regulations 2008 (Penyata Rasmi Dewan Rakyat, (Hansard Report), Parliament of Malaysia, 2004). The Malaysian PNPV Act 2004 was based on India's Protection of Plant Varieties and Farmers' Rights Act 2001 (PPVFR 2001) and slightly departs from UPOV 1991 (A Ghani Azmi, 2004). This Malaysian statue main objective is to protect plant breeders' rights over their newly created varieties (Preamble of PNVP Act 2004) while at the same time allocating specific provisions for protecting the rights of the small farmers and traditional farming communities. The question remains as to what extent this particular legislation promotes the protection of small farming communities in Malaysia as listed under Article 9 (Farmers Rights) of the FAO Treaty?

In Malaysia, protection over PGRFA under the IP regime is still new in the sense that there is a limited number of in depth researches has been done on it. The works of Manap, Zainol, Hussein, Sidik and Shafiee (2007), Kanniah (2005), Hashim and Len (2005) and A.G Azmi (2004), commented on the Plant Variety Protection Act 2004 of Malaysia in a general manner and discusses the legislation from a procedural point of view. Their writings are more on the commentary of the specific provisions of the Act rather than of its impact towards protection or recognition of small farmers or small holders in the agricultural sector. There is also currently limited legal literature that provides in depth comparison on the extent of IP protection on PGRFA and the concept of Farmers' Rights in Malaysia with those written about India's PPVFR Act which has served as model legislation for Malaysia. India's legislation was also cited as the first one in the world to provide legal recognition on Farmers' Rights in similar manner as commercial plant breeders' rights (Ramanna, \& Smale, 2004).

The Indian statue also contains specific provisions which integrate the rights of breeders of plant varieties and address the concerns of farming communities of India in the agricultural industry (Brahmi, Saxena \& Dhillon, 2004). Through this piece of legislation India has to a certain extent successfully created a sui generis system which takes into account the agricultural biotechnology processes and their impacts on farmers and seed industries of India. In contrast to India's Protection of Plant Varieties and Farmers' Rights Act in 2001 (PPVFR 2001) which devotes a whole section, Chapter VI, (Sections 39 to 46) towards creating positive rights for the farming community (Sahai, 2003); Malaysian's PNPV 2004 contains very few sections which refers to rights of farmers and farming community. For instance, on the rights of farmers to save seed of protected variety, Section 31(1)(e) of Malaysian 
PNPV 2004 limits sale of protected seeds by small farmers to others, only when these farmers are unable to use the saved seed for planting due to natural disasters, emergencies and other factor which is beyond their control. Singh, Manchikati and Chawla (2011) in their analysis of intellectual property sui generis legislations in Asian countries, state that Malaysia's recognition of the rights of farmers to save seed and related rights is more in the nature of exceptions to a breeder's rights rather than a stand-alone right on its own.

Farmers' Rights, as indicated earlier might be affected by trade and seed regulations either at global or national level. Stricter legislations or rules restricting farmers' access to seed saving and traditional agricultural practises would create an impact on their livelihood. Stronger IP protection on biotechnology and genetic resources may affect the accessibility and availability of agricultural products and processes to a large portion of small farmers as they are unable to afford the high cost associated with IP protected products. Haugen argues that the aggressive expansion of biotechnology in the agricultural sphere transfers power and decisions in food production and farming away from farmers into the hands of large seed producing corporations. Trade agreements and national policies which incorporate exclusive monopoly rights to these large corporations further undermine the rights of farmers to seeds and directly threaten food sovereignty of the small farmers and rural communities (Haugen, 2009; Haugen 2014).

At national level, the recent but inconclusive negotiations on the Trans-Pacific-Partnership Agreement (TPPA) and proposed National Seed Law in Malaysia have raised further concerns not only on the traditional rights of farmers in seed saving and agricultural practises but also on their rights to benefit-sharing in commercialisation of traditional plant varieteis and their involvement in decision making processes; as both rights affects their livelihood (Third World Resurgence, 2013).

To answer the above queries, it is imperative to examine on how the Malaysian PNPV Act 2004 protects the rights of small farmers and traditional communities as one of the method of ensuring the continuous source of livelihood for the farming community and towards crop genetic biodiversity conservation.

\section{Conclusion}

There is a need for a study to be conducted on the role played by the Malaysian state towards implementing and strengthening of the rights of small farmers in Malaysia under the plant variety protection law. An examination of the current Malaysian PNVP Act and the proposed National Seed Law can also assist in ascertaining the legal protection afforded to small farmers as one of the main stakeholder and producers of food crops. Further research into the role and legal rights of farmers,' particularly small farmers in the protection of crop and genetic biodiversity can assist the policy makers in formulating development programmes which would be not only benefit small farmers economically but at the same time contribute to a secure and continuous food production.

\section{References}

A. G. Azmi, I.M. (2004). The Protection of Plant Varieties in Malaysia. Journal of World 
Intellectual Property, 7(6), 877-890. http://dx.doi.org/10.1111/j.1747-1796.2004.tb00232.x

Alam, M.M., Siwar, C., Murad, M.W., Molla, R.M., Toriman, M.E. (2010) Socioeconomic Profile of Farmer In Malaysia: Study On Integrated Agricultural Development Area In North-West Selangor, Agricultural Economics and Rural Development, New Series, Year VII, no. 2, 249-265.

Altieri, M.A. (2009). Agroecology, Small Farms and Food Sovereignty. Monthly Review, 61(3), 102-114. http://dx.doi.org/10.14452/MR-061-03-2009-07_8

Andersen, R. (2008). Governing Agro biodiversity: Plant Genetics and Developing Countries. Hampshire,UK: Ashgate Publishing Limited.

Biber-Klemm, S \& Cottier, T. (2006). (eds.), Rights to Plant Genetic Resources and Traditional Knowledge: Basic Issues and Perspective. Oxfordshire, UK: CABI Publishing.

Borowiak, C. (2004). Farmers' Rights: Intellectual Property Regimes and the Struggle over Seeds. Politics and Society, 32(4), 511-543. http://dx.doi.org/10.1177/0032329204269979

Brahmi, P., Saxena, S. \& Dhillon, B.S. (2004). The Protection of Plant Varieties and Farmers' Rights Act of India. Current Science, 86(3), 392

Brush, B. (2007).Farmers' Rights and Protection of Traditional Agricultural Knowledge. World Development, 35(9), 1499-1514. http://dx.doi.org/10.1016/j.worlddev.2006.05.018

Fahmi, Z., Abu Samah, B \& Abdullah, H. (2013) Paddy Industry and Paddy Farmers Well-being: A Success Recipe for Agriculture Industry in Malaysia. Asian Social Science; 9(3), 177-181. http://dx.doi.org/10.5539/ass.v9n3p177

Food and Agriculture Organisation. (1998). The State of the World's Plant Genetic Resources for Food and Agriculture. Food and Agriculture Organization.

Fowler, C. \& Hodgkin, T. (2004). Plant Genetic Resources for Food and Agriculture: Assessing Global Availability. Annual Review of Environment and Resources, 29. http://dx.doi.org/10.1146/annurev.energy.29.062403.102203

Gibson, M. 2012, The Feeding of Nations: Redefining Food Security for the $21^{\text {st }}$ century, CRC Press Inc., p 284-285. http://dx.doi.org/10.1201/b11576

Girsberger, M. (1999). Biodiversity and the Concept of Farmers' Rights in International Law: Factual Background and Legal Analysis. Peter Lang AG, European Academic Publisher.

Haugen, H.M. (2009). Food Sovereignty - An Appropriate Approach to Ensure the Right to Food?. Nordic Journal of International Law, 78, 263- 292. http://dx.doi.org/10.1163/090273509X12448190941048

Haugen, H.M. (2014). How are Indigenous and Local Communities' Rights over Their Traditional Knowledge and Genetic Resources Protected in Current Free Trade Negotiations? Highlighting the Draft Trans-Pacific Partnership Agreement (TTPA). Journal of World Intellectual Property, 17(3-4), 81-95. http://dx.doi.org/10.1002/jwip.12021 
Kanniah, R. (2005). Plant Variety Protection in Indonesia, Malaysia, the Philippines and Thailand, Journal of World Intellectual Property, 8.

Lindsay J Falvey, L. J. (2010). Small Farmers Secure Food: Survival Food Security, the World's Kitchen and the Crucial Role of Small Farmers, Thaksin University Book Center in association with Institute for International Development, Australia, Songkhla, Thailand

Manap, N. A., Zainol, Z. A., Hussein, S. M., Sidik, N. M. \& Shafiee, R. (2007). The Intellectual Property Rights for New Plant Varieties: A Malaysian Perspective. Paper presented at BILETA Conference

Moore, G \& Tymowski, W. (2005). Explanatory Guide to International Treaty on Plant Genetic Resources for Food and Agriculture. Gland, Switzerland: International Union for Conservation of Nature and natural Resources (IUCN). http://dx.doi.org/10.2305/IUCN.CH.2005.EPLP.57.en

Mushita, A.T. (1992). Seed Improvement and Farmers' Rights in Zimbabwe. In (eds.) H. Brouwer, E. M. Stokhof \& J. F.G. Bunders (Eds.), Biotechnology and Farmers' Rights: Opportunities and Threats for Small-scale Farmers in Developing Countries, Amsterdam: VU University Press.

Oguamanam, C. (2006). Intellectual Property Rights in Plant Genetic Resources: Farmers' Rights and Food Security of Indigenous and Local Communities. Drake Journal of Agricultural Law, 11, 274-277.

Parliament of Malaysia. (2004). Penyata Rasmi Dewan Rakyat (Hansard Report in Malay Language), Bil.17, 14 June 2004, 48-50.

Ramanna, A. \& Smale, M. (2004). Rights and Access to Plant Genetic Resources under India's New Law, Development Policy Review, 22(4), 423-442. http://dx.doi.org/10.1111/j.1467-7679.2004.00258.x

S. M. Hashim, S.M., \& Len, D. (2005). Plant Intellectual Property: A Look at the Protection of New Plant Varieties Act 2004 (Act 634), Malayan Law Journal,

Saad, N., Sperling, L. \& Ashby, J. A. (2009). Farmers and Plant Genetic Resources, Biotechnology: Agricultural Biotechnology, Vol. VIII, Encyclopedia of Life Support Systems (EOLSS). Oxford, UK: EOLSS Publishers.

Sahai, S. (2003). India's Plant Variety Protection and Farmers' Rights Act 2001, Current Science, 84(3), 411

Singh, A.P., Manchikanti, P., \& Chawla, H.S. (2011). Sui generis IPR Laws vis-a-vis Farmers' Rights in some Asian countries: Implications under the WTO. Journal of Intellectual Property Rights, 16(2), 107-116.

Southern and Eastern African Trade Information and Negotiations Institute (SEATINI). (2010). Uganda's Plant Variety Protection Bill, 2010: Where are the Smaller Farmer's and Community

Rights?' 


\section{Macrothink}

Journal of Management Research

ISSN 1941-899X 2015, Vol. 7, No. 2

$<$ http://www.seatiniuganda.org/downloads/Reports/ugandas\%20plant\%20variety\%20bill.pdf $>$,

Swaminathan, M.S. (1998). Farmers' Rights and Plant Genetic Resources. Biotechnology and Development Monitor, No. 36,

Third World Network. (2013). The TPPA: A Threat to National Sovereignty and Development, Third World Resurgence, Issue No.275, July 2013

\section{Copyright Disclaimer}

Copyright for this article is retained by the author(s), with first publication rights granted to the journal.

This is an open-access article distributed under the terms and conditions of the Creative Commons Attribution license (http://creativecommons.org/licenses/by/3.0/). 